Article

\title{
Production of Resveratrol by Piceid Deglycosylation Using Cellulase
}

\author{
Chia-Hung Kuo ${ }^{1}$, Bao-Yuan Chen ${ }^{2}$, Yung-Chuan Liu ${ }^{3}$, Jiann-Hwa Chen ${ }^{2}$ and \\ Chwen-Jen Shieh ${ }^{4, *}$
}

1 Department of Seafood Science, National Kaohsiung Marine University, Kaohsiung 81157, Taiwan; chkuo@webmail.nkmu.edu.tw

2 Graduate Institute of Molecular Biology, National Chung Hsing University, Taichung 402, Taiwan; boq609@gmail.com (B.-Y.C.); jhchen@dragon.nchu.edu.tw (J.-H.C.)

3 Department of Chemical Engineering, National Chung Hsing University, Taichung 402, Taiwan; ycliu@dragon.nchu.edu.tw

4 Biotechnology Center, National Chung Hsing University, Taichung 402, Taiwan

* Correspondence: cjshieh@dragon.nchu.edu.tw; Tel.: +886-4-2284-0450 (ext. 5121); Fax: +886-4-2286-1905

Academic Editor: David D. Boehr

Received: 15 December 2015; Accepted: 16 February 2016; Published: 24 February 2016

\begin{abstract}
Resveratrol is a dietary polyphenolic compound widely used in medicine, food, and cosmetic products. The glycoside form of resveratrol, piceid, is also present in several plant materials but is less bioavailable. In this study, enzymatic transformation of piceid into resveratrol using inexpensive cellulase was investigated. Response surface methodology was used to evaluate the effect of reaction parameters, including reaction temperature, reaction time, enzyme amount and $\mathrm{pH}$. The optimal conditions for biotransformation of piceid to resveratrol are: a reaction temperature of $50{ }^{\circ} \mathrm{C}$, reaction time of $4.75 \mathrm{~h}$, enzyme amount of 2.5 fungal $\beta$-glucanase (FBG) units and $\mathrm{pH}$ of 4.3. In addition, the extracts from Polygonum cuspidatum root contained high amounts of piceid were treated with cellulase in order to deglycosylation that increased resveratrol yield. After treatment, the resveratrol yield significantly increased from 2.72 to $9.49 \mathrm{mg} / \mathrm{g}$, while the piceid contents decreased from 8.60 to $0 \mathrm{mg} / \mathrm{g}$. The result provides an efficient method to convert piceid in the extracts of P. cuspidatum root into resveratrol by cellulase.
\end{abstract}

Keywords: cellulase; piceid; resveratrol; Polygonum cuspidatum; enzymatic transformation

\section{Introduction}

Natural polyphenolic compounds are usually secondary plant metabolites. Of them, phytoalexins are synthesized only in response to infection or injury and play an important role in the defense of plants against pathogens, parasites and UV radiation. Resveratrol (trans-3,5, $4^{\prime}$-trihydroxystilbene) is a kind of phytoalexin belonging to the stilbene family [1]. It is present in natural foods and beverages (e.g., in grapes and red wine) and is widely consumed [2,3]. It has been suggested that moderate drinking of red wine helps to prevent cardiovascular disease; resveratrol in red wine is believed to be the key molecule due to its inhibitory activities against platelet aggregation and oxidation of low-density lipoprotein (LDL) in blood [4]. Resveratrol is also recognized as a bioactive agent with potent anti-inflammatory, antioxidant, anti-proliferative, and cancer chemopreventive activities $[5,6]$.

Resveratrol exists in a variety of vegetable foods, such as Vaccinium spp. (including blueberry, bilberry, and cranberry), peanut and huzhang (Polygonum cuspidatum) [7-9]. In these foods, a glycosylated derivative of resveratrol, piceid (3,5, $4^{\prime}$-trihydroxystilbene-3-O- $\beta$-D-glucopyranoside), is also present in good quantity [10]. Piceid is the major derivative of resveratrol in many plants 
and is usually present in much higher amounts than resveratrol itself. The amount of piceid has been reported to be 3-7 times higher than that of resveratrol in grape berry skins, hop cones, grape juices, P. cuspidatum roots and cocoa-containing products [11-13]. It should be kept in mind that glycosylation of piceid to the resveratrol 3,5- $\beta$-D-diglucoside form increased the water solubility 1700-fold as compared to resveratrol [14]. The modification of resveratrol to affect its bioactivity may be useful for specific applications. This implies that whatever method is chosen for resveratrol modification, site selectivity requires special attention [14-16]. However, the bioavailability of piceid is lower than that of resveratrol. Studies have shown that resveratrol is absorbed more easily and rapidly than piceid by human intestinal cells [17]. Henry et al. have reported that piceid cannot be absorbed by the transport system located in the apical membrane of human intestinal Caco-2 cells [18], probably because resveratrol has a higher affinity toward the lipid bilayer of the cellular membrane than piceid. In in vitro tests, resveratrol metabolites did not elevate endothelial nitric oxide synthase enzyme activity and endothelial NO release or affect intracellular reactive oxygen species levels [19]. In order to increase the production of resveratrol, it is important to develop a deglycosylation technique to transform piceid in plant or food materials into resveratrol.

Deglycosylation can be achieved by chemical or enzymatic methods. In general, the chemical method uses acid or alkali as the hydrolytic reagent and often requires high temperatures or long incubation times, which may lead to further degradation of the hydrolysate (containing resveratrol and/or piceid). The hydrolysis of P. cuspidatum root by $\mathrm{H}_{2} \mathrm{SO}_{4}$ solution failed due to the fact resveratrol was substantially destroyed during the process [20]. In contrast, enzymatic hydrolysis usually takes place at moderate $\mathrm{pH}$ and temperature and is an environmental-friendly process without generation of toxic or degraded products [21,22]. $\beta$-Glucosidase has been used for deglycosylation of isoflavone glucosides in soymilk into their aglycones [23] and for hydrolysis of resveratrol glucosides in wine in order to analyze the total wine resveratrol [24]. However, the high cost of $\beta$-glucosidase is the major concern of enzymatic transformation reactions for industrial applications. The cost of enzymes is currently major factor limiting the commercialization on the enzymatic deglycosylation of natural botanical active ingredients for industrial production [25]. Aspergillus species are efficient producers of cellulase [26,27]. Cellulase is a multi-component carbohydrase presenting endo-1,4- $\beta$-glucanase (EC 3.2.1.4), exo-1,4- $\beta$-glucanase (EC 3.2.1.91) and $\beta$-glucosidase (EC 3.2.1.21) activities, which breaks down cellulose through synergistic action [28,29]. Currently, enzyme cost is also the major concern of biofuel production from cellulosic biomass [30,31]. Literature estimates for the cost contribution of enzymes to the production of lignocellulosic ethanol vary significantly from 0.1 to 0.4 USD per gallon [32]. With the development of biomass ethanol, the cellulase cost will be gradually reduced. In contrast, natural botanical active ingredients are usually sold at a high price so the enzyme cost will become acceptable if the cost is around 0.1 0.4 USD per gallon product. Compared to the high price of $\beta$-glucosidase on the market, cellulase is relatively inexpensive and could be used in the food industry to transform piceid into resveratrol or deglycosylation of nature botanical compounds from plant materials.

Response surface methodology (RSM) is a combination of mathematical and statistical techniques. It can be used for designing experiments, building models, evaluating the relative significance of the reaction variables, and determining the optimum conditions for the desired responses [33]. Optimization of enzyme loading and the operating condition can improve the yield of products and thus cut down the cost [34]. In this study, the enzymatic transformation of piceid to the aglycone form resveratrol using cellulase was investigated. Statistical experiment design and response surface methodology (RSM) analysis were employed to understand the relationship between the reaction variables (temperature, time, enzyme amount and $\mathrm{pH}$ ) and the conversion. The optimal transformation condition was obtained and tested experimentally with extracts of P. cuspidatum root. 


\section{Results and Discussion}

\subsection{Model Fitting}

The main objective of this work was to develop a statistical approach to understand the relationship between the variables and the response (conversion) of an enzymatic reaction, i.e., hydrolysis of piceid to resveratrol by cellulase. Factors that may affect the reaction include enzyme loading and reaction conditions (e.g., temperature, time, $\mathrm{pH}$ ). In order to obtain a high conversion yield and reaction rate, optimization of the process is required [35]. In comparison with the one-factor-at-a-time design, RSM, as employed in this study, is more efficient in reducing the experimental runs and time for determination of the optimal condition. The experimental conditions and the response values of the experimental design are listed in Table 1 . The highest conversion $(98.39 \% \pm 0.33 \%)$ was obtained at $55^{\circ} \mathrm{C}$ for $6 \mathrm{~h}$ with enzyme amount $1.75 \mathrm{FBG}$ and $\mathrm{pH} 4$ (run No. 11), and the lowest conversion $(0.37 \% \pm 0.04 \%)$ was obtained at $55{ }^{\circ} \mathrm{C}$ for $3.5 \mathrm{~h}$ with enzyme amount 1.75 FBG and pH 2 (run No. 27). The manipulated variables and the responses were analyzed to fit a regression model, and the second-order polynomial model is as follows:

$$
\begin{gathered}
Y(\%)=-818.7237+17.2035 X_{1}+47.0162 X_{2}+73.6631 X_{3}+130.1544 X_{4}-0.15685 X_{1}^{2}- \\
0.42367 X_{1} X_{2}-0.58499 X_{1} X_{3}+0.33325 X_{1} X_{4}-3.38922 X_{2}^{2}+1.65982 X_{2} X_{3}+1.55617 X_{2} X_{4} \\
-10.9288 X_{3}^{2}+1.95963 X_{3} X_{4}-18.359 X_{4}{ }^{2}
\end{gathered}
$$

where $Y$ is the predicted conversion; $X_{1}$ is the temperature; $X_{2}$ is the time; $X_{3}$ is the enzyme amount; $\mathrm{X}_{4}$ is the $\mathrm{pH}$.

\begin{tabular}{|c|c|c|c|c|c|}
\hline \multirow[b]{2}{*}{ Run } & \multicolumn{4}{|c|}{ Independent Variable } & \multirow{2}{*}{$\begin{array}{l}\text { Conversion(\%) } \\
\text { Actual Values }{ }^{a}\end{array}$} \\
\hline & $\begin{array}{c}X_{1}\left({ }^{\circ} \mathrm{C}\right) \\
\text { Temperature }\end{array}$ & $\begin{array}{c}X_{2}(h) \\
\text { Time }\end{array}$ & $\begin{array}{c}X_{3}(\mathrm{FBG}) \\
\text { Enzyme Amount }\end{array}$ & $\begin{array}{l}X_{4} \\
p H\end{array}$ & \\
\hline 1 & 45 & 4.75 & 2.5 & 3 & $68.31 \pm 3.71$ \\
\hline 2 & 35 & 3.5 & 1.75 & 4 & $39.04 \pm 3.18$ \\
\hline 3 & 55 & 3.5 & 1.75 & 6 & $19.01 \pm 0.04$ \\
\hline 4 & 55 & 3.5 & 1.75 & 4 & $80.91 \pm 1.95$ \\
\hline 5 & 65 & 4.75 & 2.5 & 5 & $49.04 \pm 7.55$ \\
\hline 6 & 45 & 2.25 & 2.5 & 5 & $52.25 \pm 5.41$ \\
\hline 7 & 65 & 2.25 & 2.5 & 5 & $39.88 \pm 1.78$ \\
\hline 8 & 45 & 2.25 & 1 & 5 & $30.34 \pm 2.03$ \\
\hline 9 & 55 & 3.5 & 1.75 & 4 & $82.26 \pm 2.70$ \\
\hline 10 & 45 & 4.75 & 1 & 3 & $27.13 \pm 0.17$ \\
\hline 11 & 55 & 6 & 1.75 & 4 & $98.39 \pm 0.33$ \\
\hline 12 & 55 & 1 & 1.75 & 4 & $25.49 \pm 0.48$ \\
\hline 13 & 65 & 2.25 & 2.5 & 3 & $2.17 \pm 0.09$ \\
\hline 14 & 65 & 4.75 & 1 & 3 & $1.23 \pm 0.04$ \\
\hline 15 & 65 & 4.75 & 2.5 & 3 & $2.50 \pm 0.18$ \\
\hline 16 & 65 & 2.25 & 1 & 5 & $20.03 \pm 0.80$ \\
\hline 17 & 55 & 3.5 & 1.75 & 4 & $75.24 \pm 1.64$ \\
\hline 18 & 45 & 4.75 & 2.5 & 5 & $84.21 \pm 2.66$ \\
\hline 19 & 55 & 3.5 & 0.25 & 4 & $19.84 \pm 1.25$ \\
\hline 20 & 55 & 3.5 & 3.25 & 4 & $97.24 \pm 1.01$ \\
\hline 21 & 65 & 2.25 & 1 & 3 & $1.01 \pm 0.08$ \\
\hline 22 & 65 & 4.75 & 1 & 5 & $31.83 \pm 2.20$ \\
\hline 23 & 45 & 2.25 & 1 & 3 & $14.23 \pm 0.21$ \\
\hline 24 & 45 & 4.75 & 1 & 5 & $56.85 \pm 0.75$ \\
\hline 25 & 45 & 2.25 & 2.5 & 3 & $33.44 \pm 1.33$ \\
\hline 26 & 75 & 3.5 & 1.75 & 4 & $1.73 \pm 0.10$ \\
\hline 27 & 55 & 3.5 & 1.75 & 2 & $0.37 \pm 0.04$ \\
\hline
\end{tabular}

Table 1. Central composite design and observed experimental data for 5-level-4-factor response surface analysis.

${ }^{\mathrm{a}}$ Mean of duplicate determinations. 
Analysis of variance (ANOVA) was performed for the fitness of the model to the experimental data. The significance of each coefficient was determined by $p$-value and $p<0.05$ indicates that the model term affects the hydrolytic process significantly. As shown in Table 2, the statistical analysis demonstrated that all of the four linear model terms, i.e., $X_{1}$ (temperature), $X_{2}$ (time), $X_{3}$ (enzyme amount) and $X_{4}(\mathrm{pH})$, affected the process significantly $(p<0.05)$. The quadratic terms of $X_{1}{ }^{2}, X_{2}{ }^{2}$, and $X_{4}{ }^{2}$ also affected the process significantly, of which $X_{1}^{2}$ and $X_{4}^{2}$ affected the process most significantly $\left(p=0.0001\right.$ and $<0.0001$, respectively). In contrast, all of the other interaction terms $\left(X_{1} X_{2}, X_{1} X_{3}, X_{1} X_{4}\right.$, $X_{2} X_{3}, X_{2} X_{4}$ and $\left.X_{3} X_{4}\right)$ did not affect the process significantly $(p>0.05)$. The coefficient of determination $\left(R^{2}\right)$ of this model was 0.92 , indicating excellent correlation between the independent variables. The $p$-value for lack of fit was 0.0669 , indicating statistically insignificant lack of fit. The analysis of variance (ANOVA) indicated that the second-order polynomial model was an adequate representation of the actual relationship between the response and the significant variables.

Table 2. ANOVA for response surface models of all independent variables.

\begin{tabular}{|c|c|c|c|c|}
\hline \multirow{2}{*}{ Factor $^{a}$} & \multicolumn{4}{|c|}{ Conversion $(Y)$} \\
\hline & Sum of Squares & df & F-Value & Prob $>F$ \\
\hline Model & $23,999.79$ & 14 & 10.17 & $0.0001 *$ \\
\hline \multicolumn{5}{|c|}{ Linear term } \\
\hline$X_{1}$ & 3594.42 & 1 & 21.34 & $0.0006^{*}$ \\
\hline$X_{2}$ & 3118.40 & 1 & 18.51 & $0.0010 *$ \\
\hline$X_{3}$ & 3849.26 & 1 & 22.85 & 0.0004 * \\
\hline$X_{4}$ & 2639.37 & 1 & 15.67 & 0.0019 * \\
\hline \multicolumn{5}{|c|}{ Quadratic } \\
\hline$X_{1}^{2}$ & 5248.53 & 1 & 31.1 & $0.0001 *$ \\
\hline$X_{2}^{2}$ & 598.27 & 1 & 3.55 & 0.0839 \\
\hline$X_{3}^{2}$ & 806.20 & 1 & 4.78 & $0.0492 *$ \\
\hline$X_{4}^{2}$ & 7190.4 & 1 & 42.69 & $<0.0001$ * \\
\hline \multicolumn{5}{|c|}{ Interactions } \\
\hline$X_{1} X_{2}$ & 448.74 & 1 & 2.66 & 0.1285 \\
\hline$X_{1} X_{3}$ & 307.99 & 1 & 1.82 & 0.2012 \\
\hline$X_{1} X_{4}$ & 177.68 & 1 & 1.05 & 0.3246 \\
\hline$X_{2} X_{3}$ & 38.74 & 1 & 0.23 & 0.6401 \\
\hline$X_{2} X_{4}$ & 60.54 & 1 & 0.35 & 0.5599 \\
\hline$X_{3} X_{4}$ & 34.56 & 1 & 0.20 & 0.6586 \\
\hline Residual & 2020.83 & 12 & - & - \\
\hline Lack of Fit & 1993.05 & 10 & 14.34 & 0.0669 \\
\hline Pure Error & 27.78 & 2 & - & - \\
\hline R-Squared & 0.92 & - & - & - \\
\hline
\end{tabular}

\subsection{Response Surface Analysis}

The effects of reaction temperature ranging from 45 to $65^{\circ} \mathrm{C}$, reaction time ranging from 1 to $6 \mathrm{~h}$ and their mutual interaction on the yield with enzyme amount of $1.75 \mathrm{FBG}$ and $\mathrm{pH}$ of 4 were further investigated. As shown in Figure 1a, a quadratic effect of both variables was observed, but reaction time had greater influence on the resveratrol yield than temperature. The increase in reaction time from $1 \mathrm{~h}$ to $6 \mathrm{~h}$ led to a curvilinear increase in yield from $\sim 25 \%$ to $\sim 90 \%$ at a given temperature between $45{ }^{\circ} \mathrm{C}$ and $50{ }^{\circ} \mathrm{C}$ and from $\sim 20 \%$ to $\sim 60 \%$ at a given temperature higher than $60{ }^{\circ} \mathrm{C}$. This indicates that excessive heat energy inhibited enzyme activity by thermal denaturation. Takada et al. expressed $\beta$-glucosidase of A. aculeatus in Saccharomyces cerevisiae and found that while the optimal temperature of $\beta$-glucosidase activity was $50^{\circ} \mathrm{C}$, and the enzyme was stable below $50^{\circ} \mathrm{C}$ [36]. Figure $1 \mathrm{~b}$ shows 
the effects of enzyme amount, reaction time and their mutual interaction on the resveratrol yield at reaction temperature of $55^{\circ} \mathrm{C}$ and $\mathrm{pH}$ of 4 . The yield increased with the increases of enzyme amount and reaction time. The resveratrol yield gradually leveled off at a higher enzyme amount, suggesting that sufficient amount of enzyme is achieved for transformation of piceid to resveratrol in this system. Since an excessive amount of enzyme did not effectively increase the yield, the amount of enzyme should be minimized in order to save cost. A reaction with reaction time of $6 \mathrm{~h}$, enzyme amount of $2.75 \mathrm{FBG}$, reaction temperature of $55^{\circ} \mathrm{C}$ and $\mathrm{pH}$ of 4 led to $90 \%$ yield (Figure 1b). Figure $1 \mathrm{c}$ shows the effects of $\mathrm{pH}$, reaction time and their mutual interaction on the resveratrol yield and with enzyme amount of $1.75 \mathrm{FBG}$ and reaction temperature of $55^{\circ} \mathrm{C}$. With this fixed enzyme amount and reaction temperature, $\mathrm{pH}$ affected enzyme activity significantly. With a given reaction time between $1 \mathrm{~h}$ and $6 \mathrm{~h}$, the yield gradually increased to an optimum as the $\mathrm{pH}$ increased from 3 to 4.3 , but decreased as the $\mathrm{pH}$ more than 4.3. This is consistent with the results from a previous study in which the optimal $\mathrm{pH}$ of $\beta$-glucosidase from $A$. aculeatus was between 4 and 5 [36].

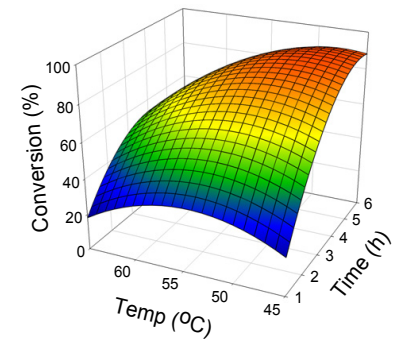

(a)

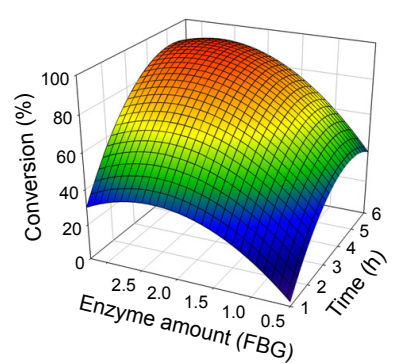

(b)

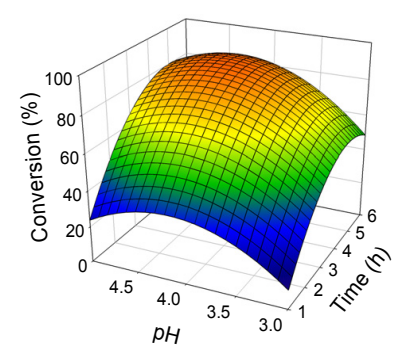

(c)

Figure 1. Response surface plot showing the relationships between resveratrol yield and reaction parameters: (a) reaction time and temperature; (b) reaction time and enzyme amount; and (c) reaction time and $\mathrm{pH}$.

\subsection{Attaining the Optimum Condition}

The planned series of contour plots were generated from the predicted model (Equation (1)) by holding constant at a specific enzyme amount $(1,1.25$, or 2.5 FBG) and $\mathrm{pH} 4$, which are shown in Figure $2 \mathrm{a}-\mathrm{c}$, respectively. With this fixed $\mathrm{pH}$, the yield increased with the increase in enzyme amount or reaction time, but the yield decreased with the increase in reaction temperature. The reaction time of $4.75 \mathrm{~h}$, temperature of $50^{\circ} \mathrm{C}$, enzyme amount of $2.5 \mathrm{FBG}$, and $\mathrm{pH}$ of 4.3 , (Figure 2c) possessed the highest predicted conversion with less reaction time required. Under these optimal conditions, the experimental results showed all the piceid was transformed into resveratrol.

(a) Enzyme amount 1 FBG

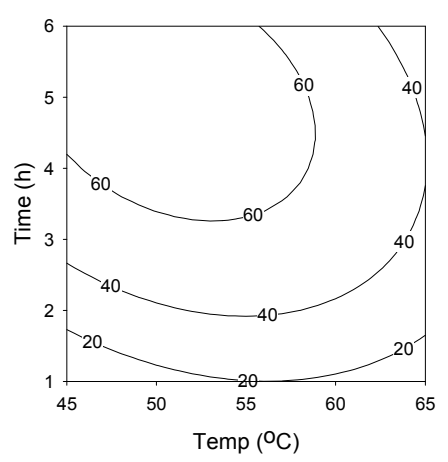

(b) Enzyme amount 1.75 FBG

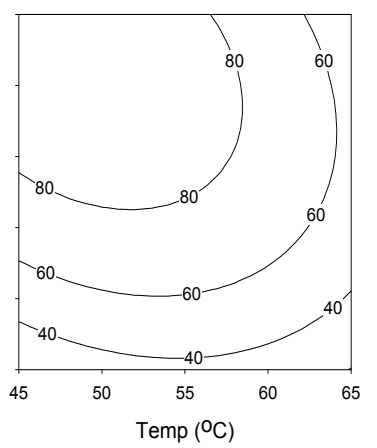

(c) Enzyme amount 2.5 FBG

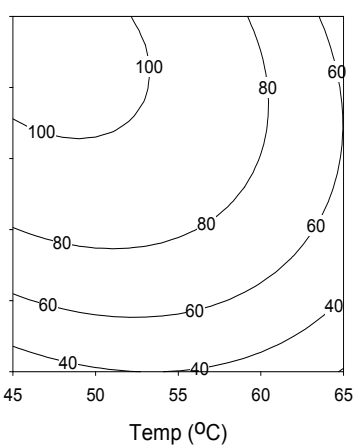

Figure 2. Contour plots of conversion of piceid to resveratrol with varying reaction temperature and times at constant enzyme amounts of (a) 1 ; (b) 1.75 and (c) 2.5 FBG. The numbers inside the contour plots indicate conversions under given reaction conditions. 


\subsection{Transformation of Piceid in the Extracts of P. cuspidatum Root}

The optimum predicted conditions were tested with extracts of P. cuspidatum root which contained high amounts of piceid. A simple HPLC method was developed using a reversed phase C8 column with a gradient elution from $10 \%$ to $100 \%$ methanol. UV detection at $303 \mathrm{~nm}$ was used to enable detection of smaller amounts of piceid and resveratrol. Figure 3 shows two representative chromatograms of the extracts of P. cuspidatum root before and after cellulase treatment. It can be seen that the piceid peak is much higher than the resveratrol one in the extracts. However, the piceid was nearly transformed to resveratrol after cellulase treatment. As Figure 4 shows, the contents of piceid and resveratrol were determined to be $8.60 \mathrm{mg} / \mathrm{g}$ and $2.72 \mathrm{mg} / \mathrm{g}$, respectively, in the extracts of P. cuspidatum root. After treatment with cellulase under the optimum conditions (reaction time of $4.75 \mathrm{~h}$, temperature of $50{ }^{\circ} \mathrm{C}$, enzyme amount of 2.5 FBG, and pH of 4.3), the contents of piceid and resveratrol in the extracts were $0 \mathrm{mg} / \mathrm{g}$ and $9.49 \mathrm{mg} / \mathrm{g}$, respectively. All the piceid in the extracts was completely converted into resveratrol by cellulase under the optimum conditions. The resveratrol was increased by 3.5 -fold in the extracts, but the conversion of piceid to resveratrol was only 79\%. Probably, in the HPLC analysis of the extracts of P. cuspidatum root, the other compounds in the extracts influenced the quantification of the piceid or resveratrol concentrations. The P. cuspidatum fermented by A. oryzae during $24 \mathrm{~h}$ incubation converted piceid to resveratrol with the highest yield of resveratrol $13.5 \mathrm{mg} / \mathrm{g}, 3.6$-fold higher than that obtained from microwave-assisted extraction [20]. However, the optimal enzyme activity temperature is much higher than that of microbial growth in the fermentation. Therefore, the RSM model may be useful to control the enzyme activities and optimize the fermentation to increase the yield of resveratrol. An experimental proof of the fact that the enzyme mixture extracted from the digestive tract of snails with the aim of converting piceid to resveratrol was first reported [37]. The composition of Viscozyme ${ }^{\circledR}$ L employed in this study was $59.9 \%$ water, $23 \%$ sucrose, $10 \%$ sodium chloride, $7 \%$-glucanase and $0.1 \%$ potassium sorbate. Viscozyme ${ }^{\circledR} \mathrm{L}$ is produced according to FAO/WHO Expert Committee on Food Additives (JECFA) and the Food Chemical Codex (FCC) with the recommended purity specifications for food-grade enzymes. In recent years, resveratrol has become widely available as a botanical dietary supplement in the United States. Therefore, the extracts of $P$. cuspidatum root treated with Viscozyme ${ }^{\circledR}$ L contained high amounts of resveratrol that can be directly used in commercial products.

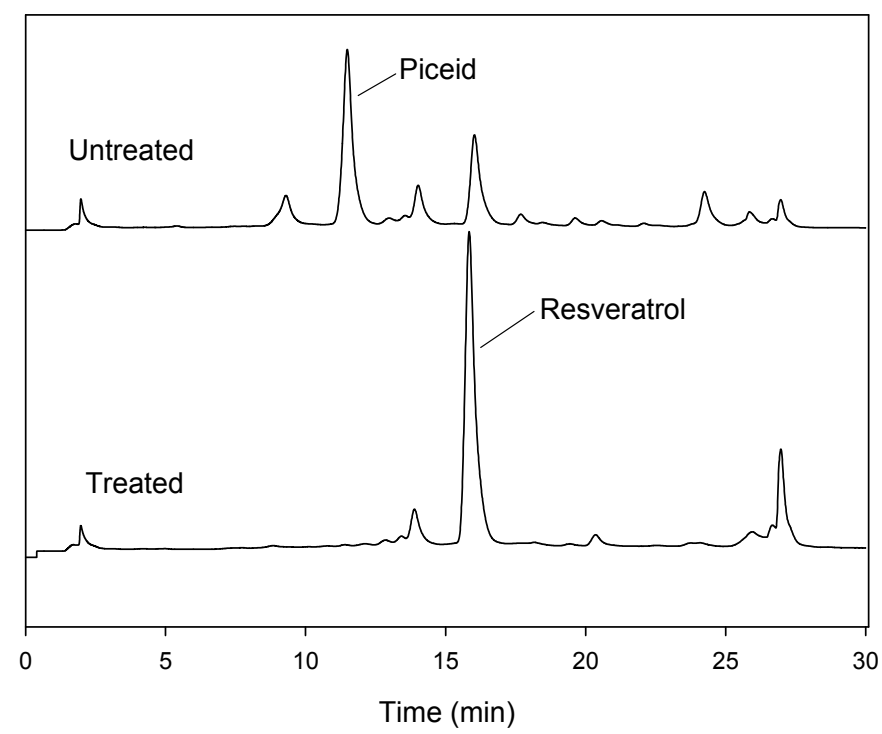

Figure 3. HPLC chromatogram of the extracts of P. cuspidatum root untreated and treated with cellulose. 


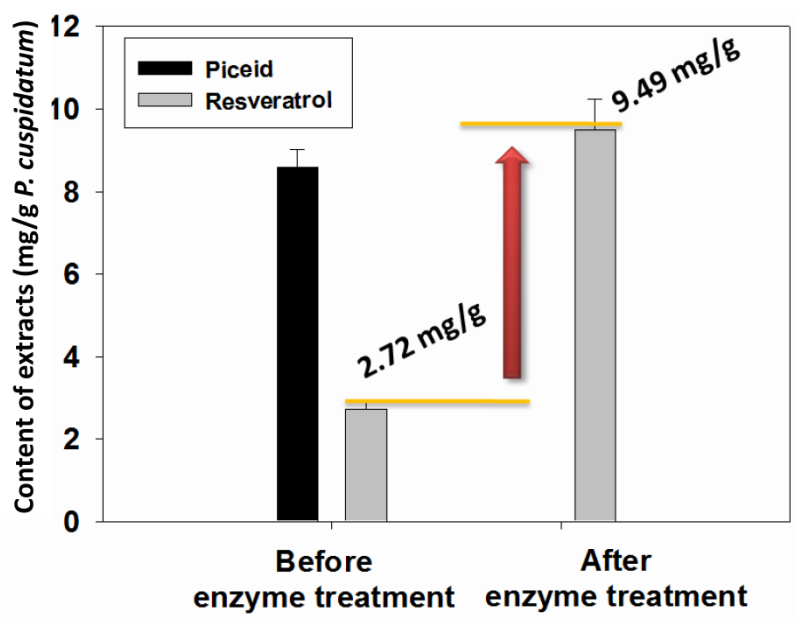

Figure 4. Cellulase-mediated transformation of piceid in the extracts of P. cuspidatum root into resveratrol under the optimum condition.

\section{Experimental Section}

\subsection{Materials}

Cellulase (Viscozyme ${ }^{\circledR}$ L (100 FBG/g), from Aspergillus aculeatus was purchased from Novozymes A/S (Bagsværd, Denmark). Piceid was purchased from Sigma-Aldrich (St. Louis, MO, USA). Resveratrol was purchased from Changsha Nutramax Biotechnology (Changsha, China). Roots of $P$. cuspidatum were provided by Jing Jiue Co., Ltd. (Taichung, Taiwan). Unless otherwise specified, all reagents and chemicals used in this study were analytical grade.

\subsection{Transformation of Piceid into Resveratrol}

Piceid solutions $(0.4 \mathrm{mg} / \mathrm{mL})$ were prepared in $50 \mathrm{mM}$ phosphate buffer at $\mathrm{pH}$ values ranging from 3 to 6 for use as substrate. Enzymatic transformation of piceid was performed in a glass tube containing $2 \mathrm{mg}$ piceid and different amounts of cellulase $(2.5-32.5 \mu \mathrm{L})$ in $5 \mathrm{~mL} 50 \mathrm{mM}$ phosphate buffer. The glass tubes were placed in an orbital shaking bath $(150 \mathrm{rpm})$ at different temperatures and for different reaction times. The reaction was terminated by addition of $5 \mathrm{~mL}$ ethanol to inactivate the cellulase. The solution was then centrifuged at 13,000 rpm for $10 \mathrm{~min}$ and the supernatant was withdrawn and analyzed by HPLC.

\subsection{Quantitation of Piceid and Resveratrol by HPLC}

Piceid and resveratrol were assayed by injecting $20 \mu \mathrm{L}$ aliquot of the sample into a HPLC system (L-7400; Hitachi, Tokyo, Japan) using a ZORBAX Eclipse XDB C8 column (5 $\mu \mathrm{M}, 250 \mathrm{~mm} \times 4.6 \mathrm{~mm})$. Deionized water and methanol containing $0.1 \%$ acetic acid were used for gradient elution from $10 \%$ to $100 \%$ methanol for $20 \mathrm{~min}$ and then elution at $100 \%$ methanol for $5 \mathrm{~min}$. The flow rate was set at $1.0 \mathrm{~mL} \cdot \mathrm{min}^{-1}$. The UV detector was set at a wavelength of $303 \mathrm{~nm}$. Calibration curves were prepared from piceid and resveratrol standards dissolved in water/ethanol (1:1). Piceid and resveratrol in samples were analyzed by comparing their retention times with those of the standards. The percent conversion of piceid to resveratrol was defined as increase of resveratrol per initial concentration of piceid $\times 100$.

\subsection{Experimental Design and Statistical Analysis}

A five-level-four-factor central composite design including 27 experiments was employed in this study. To avoid bias, the 27 runs were performed in a random order. The variables and levels selected for the 27 runs were a reaction temperature of $35-75^{\circ} \mathrm{C}$, reaction time of $1-6 \mathrm{~h}$, enzyme 
amount of $0.25-3.25 \mathrm{FBG}$ and $\mathrm{pH}$ of $2-6$ ( $50 \mathrm{mM}$ phosphate buffer, $\mathrm{pH}$ below 4 were adjusted by using $1 \mathrm{M} \mathrm{HCl})$. Table 1 shows the uncoded independent factors $\left(X_{i}\right)$, levels and experimental designs. Each experiment was carried out in duplicate. The software Design Expert (Trial Version 8.0.4, Stat-Ease Inc., Minneapolis, MN, USA) was employed for experimental design, data analysis and model building.

The data obtained from the central composite design was fitted into the quadratic polynomial model by regression analysis. The quadratic polynomial model for each response was as follows:

$$
Y=\beta_{k 0}+\sum_{i=1}^{4} \beta_{k i} X_{i}+\sum_{i=1}^{4} \beta_{k i i} X_{i}^{2}+\sum_{i=1}^{3} \sum_{j=i+1}^{4} \beta_{k i j} X_{i} X_{j}
$$

where $Y$ is the response (production rate); $\beta_{k 0}, \beta_{k i}, \beta_{k i i}$ and $\beta_{k i j}$ are constant coefficients, $X_{i}$ and $X_{j}$ are the uncoded independent variables. The adequacy of the model was determined by evaluating the lack of fit, coefficient of regression $\left(R^{2}\right)$ and the Fisher test value ( $F$-value) obtained from the analysis of variance (ANOVA). Statistical significance of the model and model variables was determined at the $5 \%$ probability level $(p<0.05)$. Three-dimensional response surface plots were generated by keeping two of the four variables (reaction temperature, reaction time, enzyme amount or $\mathrm{pH}$ ) at a fixed level and plotting that against remaining two variables.

\subsection{Transformation of Piceid into Resveratrol in the Extracts of P. cuspidatum Root}

Dried P. cuspidatum roots were ground into powder and passed through a 30 to 45 mesh sieve. The resulting powder was about $0.62 \mathrm{~mm}$ in size. One gram of the powder was extracted with $60 \mathrm{~mL}$ water in a sealed glass tube in a temperature-controlled ultrasonic bath $(40 \mathrm{kHz}, \mathrm{DC} 150 \mathrm{H}$, Delta, New Taipei, Taiwan) set at $70{ }^{\circ} \mathrm{C}$ and $150 \mathrm{~W}$ of ultrasonic power for $30 \mathrm{~min}$. After extraction, insoluble materials were removed by centrifugation at 13,000 rpm for $10 \mathrm{~min}$, and $5 \mathrm{~mL}$ was used for the transformation reaction with cellulase under the optimal condition deduced by RSM.

\section{Conclusions}

Piceid could be transformed into resveratrol by commercial cellulase from A. aculeatus, and the enzyme amount, reaction temperature, reaction time, and $\mathrm{pH}$ affected the yield significantly. A 5-level-4-factor central composite design and RSM were employed for the experimental design and data analysis, and a regression model was obtained. The optimal transformation condition to obtain $100 \%$ yield was predicted to be an enzyme amount of $2.5 \mathrm{FBG}$, temperature of $50{ }^{\circ} \mathrm{C}$, reaction time of $4.75 \mathrm{~h}$, and $\mathrm{pH}$ of 4.3 . Cellulase-mediated conversion of piceid into resveratrol under the optimum condition was tested using extracts of P. cuspidatum root. After the reaction, the resveratrol content in the extract increased from $2.72 \mathrm{mg} / \mathrm{g}$ to $9.49 \mathrm{mg} / \mathrm{g}$, but the piceid content decreased from $8.60 \mathrm{mg} / \mathrm{g}$ to $0 \mathrm{mg} / \mathrm{g}$. No piceid could be detected in the extracts after the reaction. The result provides a useful method to increase the production of resveratrol from plant materials. Cellulase is an inexpensive enzyme that has potential applications in the food industry for the large-scale transformation of piceid into resveratrol.

Acknowledgments: This work was supported by research funding grants provided by the Ministry of Science and Technology of Taiwan (MOST 104-2221-E-005-061-MY3 and MOST 104-2218-E-022-001-MY2) and was also supported in part by the Ministry of Education, Taiwan, under the ATU plan.

Author Contributions: C.J.S. and J.H.C. conceived and designed the experiments; B.Y.C. and C.H.K. performed the experiments; Y.C.L. and B.Y.C. analyzed the data; C.H.K., J.H.C. and C.J.S. wrote the paper.

Conflicts of Interest: The authors declare no conflict of interest.

\section{References}

1. Zernova, O.; Lygin, A.; Pawlowski, M.; Hill, C.; Hartman, G.; Widholm, J.; Lozovaya, V. Regulation of plant immunity through modulation of phytoalexin synthesis. Molecules 2014, 19, 7480-7496. [CrossRef] [PubMed] 
2. Zhang, A.; Fang, Y.; Li, X.; Meng, J.; Wang, H.; Li, H.; Zhang, Z.; Guo, Z. Occurrence and estimation of trans-resveratrol in one-year-old canes from seven major chinese grape producing regions. Molecules 2011, 16, 2846-2861. [CrossRef] [PubMed]

3. Kurin, E.; Mučaji, P.; Nagy, M. In vitro antioxidant activities of three red wine polyphenols and their mixtures: An interaction study. Molecules 2012, 17, 14336-14348. [CrossRef] [PubMed]

4. Baur, J.A.; Sinclair, D.A. Therapeutic potential of resveratrol: The in vivo evidence. Nat. Rev. Drug Discov. 2006, 5, 493-506. [CrossRef] [PubMed]

5. Zhang, X.; Jiang, A.; Qi, B.; Ma, Z.; Xiong, Y.; Dou, J.; Wang, J. Resveratrol protects against helicobacter pylori-associated gastritis by combating oxidative stress. Int. J. Mol. Sci. 2015, 16, 26061-27769. [CrossRef] [PubMed]

6. Jang, M.; Cai, L.; Udeani, G.O.; Slowing, K.V.; Thomas, C.F.; Beecher, C.W.; Fong, H.H.; Farnsworth, N.R.; Kinghorn, A.D.; Mehta, R.G. Cancer chemopreventive activity of resveratrol, a natural product derived from grapes. Science 1997, 275, 218-220. [CrossRef] [PubMed]

7. Chen, B.Y.; Kuo, C.H.; Liu, Y.C.; Ye, L.Y.; Chen, J.H.; Shieh, C.J. Ultrasonic-assisted extraction of the botanical dietary supplement resveratrol and other constituents of Polygonum cuspidatum. J. Nat. Prod. 2012, 75, 1810-1813. [CrossRef] [PubMed]

8. Spier, A.P.; Bavaresco, C.S.; Wyse, Â.T.; Carvalho, D.; Freitas Sarkis, J.J. Effects of resveratrol and purple grape juice on nucleotide hydrolysis by adult rat serum. Food Chem. 2007, 103, 565-571. [CrossRef]

9. Djoko, B.; Chiou, R.Y.Y.; Shee, J.J.; Liu, Y.W. Characterization of immunological activities of peanut stilbenoids, arachidin-1, piceatannol, and resveratrol on lipopolysaccharide-induced inflammation of raw 264.7 macrophages. J. Agric. Food Chem. 2007, 55, 2376-2383. [CrossRef] [PubMed]

10. Wu, C.F.; Yang, J.Y.; Wang, F.; Wang, X.X. Resveratrol: Botanical origin, pharmacological activity and applications. Chin. J. Nat. Med. 2013, 11, 1-15. [CrossRef]

11. Kuo, C.H.; Chen, B.Y.; Liu, Y.C.; Chang, C.M.; Deng, T.S.; Chen, J.H.; Shieh, C.J. Optimized ultrasound-assisted extraction of phenolic compounds from Polygonum cuspidatum. Molecules 2013, 19, 67-77. [CrossRef] [PubMed]

12. Counet, C.; Callemien, D.; Collin, S. Chocolate and cocoa: New sources of trans-resveratrol and trans-piceid. Food Chem. 2006, 98, 649-657. [CrossRef]

13. Wang, L.; Xu, M.; Liu, C.; Wang, J.; Xi, H.; Wu, B.; Loescher, W.; Duan, W.; Fan, P.; Li, S. Resveratrols in grape berry skins and leaves in Vitis germplasm. PLoS ONE 2013, 8, e61642. [CrossRef] [PubMed]

14. Lepak, A.; Gutmann, A.; Kulmer, S.T.; Nidetzky, B. Creating a water-soluble resveratrol-based antioxidant by site-selective enzymatic glucosylation. ChemBioChem 2015, 16, 1870-1874. [CrossRef] [PubMed]

15. Kuo, C.H.; Hsiao, F.W.; Dai, S.M.; Chang, C.M.J.; Lee, C.C.; Liu, Y.C.; Shieh, C.J. Lipase catalyzed acetylation of 3, 5, 4'-trihydroxystilbene: Optimization and kinetics study. Bioprocess Biosyst. Eng. 2012, 35, 1137-1145. [CrossRef] [PubMed]

16. Kuo, C.H.; Hsiao, F.W.; Chen, J.H.; Hsieh, C.W.; Liu, Y.C.; Shieh, C.J. Kinetic aspects of ultrasound-accelerated lipase catalyzed acetylation and optimal synthesis of $4^{\prime}$-acetoxyresveratrol. Ultrason. Sonochem. 2013, 20, 546-552. [CrossRef] [PubMed]

17. Signorelli, P.; Ghidoni, R. Resveratrol as an anticancer nutrient: Molecular basis, open questions and promises. J. Nutr. Biochem. 2005, 16, 449-466. [CrossRef] [PubMed]

18. Henry, C.; Vitrac, X.; Decendit, A.; Ennamany, R.; Krisa, S.; Mérillon, J.M. Cellular uptake and efflux of trans-piceid and its aglycone trans-resveratrol on the apical membrane of human intestinal caco-2 cells. J. Agric. Food Chem. 2005, 53, 798-803. [CrossRef] [PubMed]

19. Ladurner, A.; Schachner, D.; Schueller, K.; Pignitter, M.; Heiss, E.; Somoza, V.; Dirsch, V. Impact of trans-resveratrol-sulfates and -glucuronides on endothelial nitric oxide synthase activity, nitric oxide release and intracellular reactive oxygen species. Molecules 2014, 19, 16724-16736. [CrossRef] [PubMed]

20. Wang, H.; Liu, L.; Guo, Y.X.; Dong, Y.S.; Zhang, D.J.; Xiu, Z.L. Biotransformation of piceid in Polygonum cuspidatum to resveratrol by Aspergillus oryzae. Appl. Microbiol. Biotechnol. 2007, 75, 763-768. [CrossRef] [PubMed]

21. Kuo, C.H.; Lee, C.K. Enhanced enzymatic hydrolysis of sugarcane bagasse by $n$-methylmorpholine- $n$-oxide pretreatment. Bioresour. Technol. 2009, 100, 866-871. [CrossRef] [PubMed] 
22. Shafiee, A.; Tsipouras, A.; Bouffard, A.; Onishi, J.C.; Guan, Z.; Motamedi, H. Enzymatic deglycosylation of enfumafungin, a triterpene glycoside natural product, and its chemically synthesized analogues. J. Mol. Catal. B 2001, 16, 27-32. [CrossRef]

23. Horii, K.; Adachi, T.; Matsuda, T.; Tanaka, T.; Sahara, H.; Shibasaki, S.; Ogino, C.; Hata, Y.; Ueda, M.; Kondo, A. Improvement of isoflavone aglycones production using $\beta$-glucosidase secretory produced in recombinant Aspergillus oryzae. J. Mol. Catal. B 2009, 59, 297-301. [CrossRef]

24. La Torre, G.L.; Laganà, G.; Bellocco, E.; Vilasi, F.; Salvo, F.; Dugo, G. Improvement on enzymatic hydrolysis of resveratrol glucosides in wine. Food Chem. 2004, 85, 259-266. [CrossRef]

25. Matsakas, L.; Christakopoulos, P. Ethanol production from enzymatically treated dried food waste using enzymes produced on-site. Sustainability 2015, 7, 1446-1458. [CrossRef]

26. Decker, C.H.; Visser, J.; Schreier, P. $\beta$-glucosidases from five black Aspergillus species: Study of their physico-chemical and biocatalytic properties. J. Agric. Food Chem. 2000, 48, 4929-4936. [CrossRef] [PubMed]

27. Wen, Z.; Liao, W.; Chen, S. Production of cellulase/ $\beta$-glucosidase by the mixed fungi culture Trichoderma reesei and Aspergillus phoenicis on dairy manure. Process Biochem. 2005, 40, 3087-3094. [CrossRef]

28. Kuo, C.H.; Lee, C.K. Enhancement of enzymatic saccharification of cellulose by cellulose dissolution pretreatments. Carbohydr. Polym. 2009, 77, 41-46. [CrossRef]

29. Naika, G.S.; Kaul, P.; Prakash, V. Purification and characterization of a new endoglucanase from Aspergillus aculeatus. J. Agric. Food Chem. 2007, 55, 7566-7572. [CrossRef] [PubMed]

30. Humbird, D.; Davis, R.; Tao, L.; Kinchin, C.; Hsu, D.; Aden, A.; Schoen, P.; Lukas, J.; Olthof, B.; Worley, M. Process Design and Economics for Biochemical Conversion of Lignocellulosic Biomass to Ethanol: Dilute-Acid Pretreatment and Enzymatic Hydrolysis of Corn Stover; National Renewable Energy Laboratory (NREL): Golden, CO, USA, 2011.

31. Lau, M.W.; Bals, B.D.; Chundawat, S.P.; Jin, M.; Gunawan, C.; Balan, V.; Jones, A.D.; Dale, B.E. An integrated paradigm for cellulosic biorefineries: Utilization of lignocellulosic biomass as self-sufficient feedstocks for fuel, food precursors and saccharolytic enzyme production. Energy Environ. Sci. 2012, 5, 7100-7110. [CrossRef]

32. Klein-Marcuschamer, D.; Oleskowicz-Popiel, P.; Simmons, B.A.; Blanch, H.W. The challenge of enzyme cost in the production of lignocellulosic biofuels. Biotechnol. Bioeng. 2012, 109, 1083-1087. [CrossRef] [PubMed]

33. Kuo, C.H.; Chen, H.H.; Chen, J.H.; Liu, Y.C.; Shieh, C.J. High yield of wax ester synthesized from cetyl alcohol and octanoic acid by lipozyme rmim and novozym 435. Int. J. Mol. Sci. 2012, 13, 11694-11704. [CrossRef] [PubMed]

34. Taherzadeh, M.J.; Karimi, K. Enzymatic-based hydrolysis processes for ethanol. BioResources 2007, 2, 707-738.

35. Chen, J.; Liu, D.; Shi, B.; Wang, H.; Cheng, Y.; Zhang, W. Optimization of hydrolysis conditions for the production of glucomanno-oligosaccharides from konjac using $\beta$-mannanase by response surface methodology. Carbohydr. Polym. 2013, 93, 81-88. [CrossRef] [PubMed]

36. Takada, G.; Kawaguchi, T.; Sumitani, J.I.; Arai, M. Expression of Aspergillus aculeatus No. F-50 cellobiohydrolase I (cbh1) and Beta.-glucosidase 1 (bgll) genes by Sacharomyces cerevisiae. Biosci. Biotechnol. Biochem. 1998, 62, 1615-1618. [CrossRef] [PubMed]

37. Wang, Z.; Zhao, L.C.; Li, W.; Zhang, L.X.; Zhang, J.; Liang, J. Highly efficient biotransformation of polydatin to resveratrol by snailase hydrolysis using response surface methodology optimization. Molecules 2013, 18, 9717-9726. [CrossRef] [PubMed]

(C) 2016 by the authors; licensee MDPI, Basel, Switzerland. This article is an open access article distributed under the terms and conditions of the Creative Commons by Attribution (CC-BY) license (http:/ / creativecommons.org/licenses/by/4.0/). 